\title{
The Intangible Heritage of the Anthropocene: The Toponymic Revolution in the Human Age
}

\section{Gian Franco Capra and Antonio Ganga}

Dipartimento di Architettura, Design e Urbanistica, Università degli Studi di Sassari, Nuoro, Italy

\begin{abstract}
Although the Anthropocene has been approached from numerous perspectives, scholars have not as yet considered an interesting point of view. Indeed, one of the most important intangible inheritances of the Anthropocene is detectable in the deep influence on a very common, though extremely complex, "performative practice" that each one of us regularly and (often) unconsciously enacts in everyday life. Place names or toponyms are the final repository of an impressive accumulation of knowledge acquired by indigenous peoples, through long histories of conflict and interaction with their surrounding environment. During the Anthropocene, a massive toponymic revolution has modified and still characterizes several places in the world due to the considerable environmental and socio-economic changes imposed by human activities. Some worldwide cases will be presented and discussed to illustrate the importance, intensity, and pervasiveness of these Anthropocene-related human activities, as driving forces determining this unexpected and underrated revolution.
\end{abstract}

KEYWORDS Toponymy, human activities, Anthropocene, urbanonyms, technogenonyms

\section{Introduction}

Proposed for the first time in the I980s, the term Anthropocene has only relatively recently become widely, even if informally, used by scholars from different fields. It is important to note that in a relatively short time, this concept has been investigated not only by geoscientists but also by archaeologists, historians, geographers, philosophers, and gender-studies researchers (Monastersky 201 5 ).

Many of the current questions characterizing the debate about the Anthropocene epoch stem from the tangible effects of the human imprint on the 
global environment. However, there are also less palpable, imperceptible effects that can be neither ignored nor neglected. This "intangible heritage" can be identified through several perspectives, but toponymy is likely the field that better explains this concept.

Toponyms are one of the most important aspects of the intangible cultural heritage of a community, encapsulating rights to land and recalling events, activities, ideals, peoples, and knowledge (Payne 200I). The local knowledge represented by toponymy should not be seen as the counterpart to scientific knowledge, as it inevitably includes cultural as well as technical knowledge (Capra, Ganga, and Moore 20I7). Toponymy is not simply the cataloguing, classification, interpretation, and mapping of place names (Post and Alderman 20I4). It is rather the study of a complex "performative practice" (Price 2004). As a power-laden social practice (Rose-Redwood, Alderman, and Azaryahu 2010), place naming is used to construct, control, change, or even erase the identity of places and peoples living within them, often as part or consequence of larger struggles over national, regional, and racial identity among people (Post and Alderman 20I4). More simply, toponyms show the ways in which inhabitants interact with the land, and consequently, every change in land use will be recorded by toponymic inscription in a relatively short time (Capra et al. 2016).

Analogous to that of the Industrial Revolution, which has been prevalently (even if still not unanimously) indicated as being the lower boundary of the Anthropocene (Crutzen and Stoermer 2000), a significant toponymic revolution has characterized several places of the world through great changes and/or definitive loss of ancient indigenous knowledge through human activities. Indeed, while in the past, the influence of the natural surrounding environment was so significant that most toponyms were coined in order to immediately, very briefly, but exhaustively explain the main "natural" features of the landscape, this changed from the beginning of the Industrial Revolution. Following the Industrial Revolution, and even more so over the recent more "technological" decades, toponyms have been mainly used to indicate the "artificial" man-made features of an intensively anthropized environment. Although humans and the environment have interacted over a very long time period, a major revolution in the toponymy of vast areas never occurred in such a short time as in the Anthropocene. At least until the Anthropocene age, place names have been historically characterized by their intrinsic self-capacity to survive the partial or total disappearance of one language and its replacement by another by being simply passed from one generation to another (Mills 2003). Only during the Anthropocene, due to the magnitude of the impact of humankind on the surrounding environment, this important selfcapacity of toponyms appears to have been partially lost. This issue cannot be ignored because it entails several political, social, and economic repercussions that will be briefly explained in this paper.

\section{From environmental toponyms to urbanonyms and technogenonyms}

Until the significant transformation brought by urbanization, a process representing a glaring consequence of the human age, natural features of the 
landscape and early human settlements and activities were the main drivers of place-naming practice (Mills 2003). The large increase in urbanization during the Anthropocene (I750-I800 AD, with the advent of the Industrial Revolution, has usually been indicated as the beginning of this epoch) definitively changed this pattern, with human-made features of the landscape now influencing the naming of places.

Under the influence of this significant increase in urbanization, the first pivotal rationalization of urban toponymies, sometimes labelled as urbanonyms, came with the introduction of street numbering in France (Rose-Redwood 20I I) in the second half of the XVIII century. Then, toponymy became somewhat of a technocratic instrument to steer and manage urban systems, functions, and people (Hamlin I999). During the XIX century, many places in the world, especially in Europe and North America, experienced a major toponymic "modernization" (Vuolteenaho and Ainiala 2009) revolutionizing the reorganization of urban space (Rose-Redwood 20II). Toponymy in particular was used symbolically to inculcate the collective consciousness with the concepts of nation. Place names became ideological messages and a fundamental socialization strategy rooted in the setting of everyday human life (Vuolteenaho and Ainiala 2009). From this point of view, France represented once again the avant-garde of this toponymic afterthought. In Paris, in the early XIX century, the "group-naming model" (Vuolteenaho and Ainiala 2009), i.e., a series of coherent place names used along a contiguous urban landscape, was first introduced. Such a model would be progressively implemented in many other cities worldwide, such as London and Milan, representing a further means for the schematic and rational view of urban spaces (Rose-Redwood 2009) that would typically come to characterize the entire technological Anthropocene age.

In quite recent times most "modern names" have been "artificially created" without any actual description of natural features or habitations (Mills 2003). In other words, this outcome can be simply summarized as "from environmental to technogenic toponyms" (Capra et al. 20I6) or technogenonyms. This development is a radical but probably still underestimated change that, like ancient toponyms in their epoch, will probably be the "written witness" (Capra et al. 20I6) or "textual golden spikes" of the present Anthropocene age during future eras. In fact, from the beginning of the Industrial Revolution, many places have been renamed or new toponyms have been created as consequence of important industrial and engineering activities (Mills 2003). The Copperbelt Province in Zambia, the cities of Magnitogorsk and Elektrostal in Russia, the regions knows as Pays Noir (Belgium) or Black Country (Staffordshire), the Colorado Mineral Belt (Colorado) or the Mineral County (Nevada), the town of Coalville (Leicestershire) or Coalfield (Tennessee), Leadville and Oro City both in Colorado, several USA cities known as Mineral City, the town of Mineiros do Tiet $\hat{e}$ in Brazil or Carbonia in Italy, the borough of Ambridge (Pennsylvania) and the locality of Ironbridge (Shropshire) represent just a few illustrative examples in this respect. In many areas worldwide, technogenonyms now represent 
common place names in order to indicate areas with more or less diffuse human activities. For example, an integrated ethnopedological approach, conducted in an important agricultural area of southern Italy (Sardinia), demonstrated that these "artificial" man-made features, such as Irrigation Channels, Water Distribution Channels, and Spillways, are now used as "real" toponyms rather than as simple labels on a map (Capra et al. 201 5 a).

The toponymic reshaping of old "environmental names" and autochthonyms in favor of "settlement" and technogenonyms actually belong to one of the most frequently occurring categories. Additionally, if the initial names were historically assigned to large areas, the more recent names usually refer to relatively small areas (Savage 2009), even if, in qualitative terms, urban naming differs completely from the common naming of natural or, generally speaking, nonurbanized places. Consequently, urbanonymy is often considered a distinct field, separate from toponymy (Thériault 20I2). In fact, the renewed critical attention that scholars have directed to place names during the last decade (Light and Young 20I4), by using a new approach termed "critical toponymies" (Berg and Vuolteenaho 2009), has been mainly focused on urban areas where such studies predominantly investigate the politics of place-naming practices (RoseRedwood, Alderman, and Azaryahu 2010).

Urban areas are the most culturally imprinted, extensively engineered, and technologized landscapes of human habitation (Buondonno et al. 2013; Coppola et al. 20IO), and for such reasons, they are characterized by the greatest concentration of place names compared to any other human or natural world areas (Savage 2009). Urban areas are defined by their street, road names, and numbers and less so by their physical and "remnant" ancient natural landscapes. The latter are usually defined by toponyms representing an important testimony of the human and cultural transformation of the natural to the "urban" and "technological" landscape (Buondonno et al. 2018). However, there is an additional issue. In urban areas the "life expectancy" of such place names is much shorter than those usually expected for autochthonyms and toponyms which indicate natural features. Indeed, cities and related technologies continuously expand their influence, are renewed, re-planned, reorganized, (occasionally) destroyed and, consequently, rejuvenated. Moreover, as their streets continuously increase natural ancient spaces and landmarks are expunged, with dramatic landscape changes that inevitably make the city a space with no permanent identity. Additionally, the renaming of large parts of the urban landscape can also represent a prominent consequence of a radical political change. Such “toponymic cleansing” (Azaryahu 20II), representing a common political agenda of the incoming regime (Tucci, Ronza, and Giordano 20II), has been recognized in different historical frameworks of the Anthropocene such as postcolonialism, post-socialism, and even post-racism (Swart 2008). Even recently, the Americans and Shi'a communities remade Iraq's toponymy after the fall of the former regime (Rose-Redwood, Alderman, and Azaryahu 2010). However, as a "city-text," that can be often re- and over-inscribed, it is evident that any 
toponymic regime is inherently instable, historically contingent and, consequently, fleeting (Tucci, Ronza, and Giordano 20I I).

Additionally, during the Anthropocene, a new form of toponymic political agenda is now replanning the urban text. Many public authorities and local government increasingly opted for selling the naming rights of public places to corporate sponsors, becoming responsible for one of the next frontiers in the neoliberalization of urban spaces (Rose-Redwood and Alderman 20II). Even if the influence of private capital on the toponymy of the urban landscape has clear historical antecedents, both in capitalist and in socialist societies, the economic dimension of naming urban places has now become more significant (Light and Young 20I4). During the most recent Anthropocene times, both public authorities and private builders and traders increasingly brand places by bestowing them with attractive and marketable names (Vuolteenaho and Ainiala 2009). Such entrepreneurial toponymy, emerging from strong public-private partnerships, represent a new approach in urban landscape governance, in which the business and corporate world seems to have limitless power (Light and Young 20I4). Indeed, as argued by Rose-Redwood (20II), the toponymic landscape of the next century will likely be reshaped by the commercialization of the public place-naming system. In their recent research, Light and Young (2014) powerfully illustrated how the privatization of naming rights (both of public and of private sectors) can be an issue involving different urban concerns. For instance, many companies have acquired the naming rights of several stadiums and arenas through large financial payments. While such business practices have been quite common in the USA since 1973, they remain an almost new phenomenon in European countries. In England, several soccer societies of the Premier League (such as Bolton, Swansea, Arsenal, Manchester City, Manchester United, and Newcastle United) have been temporarily or permanently involved in this market (Light and Young 20I4). This emerging phenomenon is now becoming common in other European countries such as Italy where the Udinese football club recently renamed the new stadium as Dacia Stadium; and Germany, where Allianz Arena the conflict between economic interests and international rules. Because FIFA and UEFA demonstrates formally restrict the use of commercial sponsors in stadium naming, during the 2006 World Cup the lettering was removed and the stadium temporarily renamed as FIFA World Cup Stadium Munich. Following the same pharisaic approach, the logotype is turned off and the stadium becomes the Fußball Arena München during UEFA Champions League matches.

In various worldwide cities, both single subway stations (Las Vegas, New York, Philadelphia, Dubai, and Budapest) and entire transport lines (Tampa) have been renamed by commercial sponsors. Overall, there are numerous worldwide examples of local authorities that renamed buildings, streets, stadiums, subway stations, transport lines, urban neighborhoods, or even the town itself (such as McGillicuddy City in North Dakota, SecretSanta.com in Idaho or even Toyota in Japan) in order to receive large payments from the private sector. Because local 
authorities recognize a chronic lack of public resources for new infrastructure investments, the sale of naming rights now represents and will continue to represent, with increasing emphasis in the coming years, an important method of generating additional private sector investment (Light and Young 20I4).

On the whole, place names in urban areas can be seen as different historical and cultural layers. Tucci, Ronza, and Giordano (20II) proposed the suggestive metaphor of the cityscape as a multicolor "tapestry" in order to highlight the co-existence of many different narratives and conflicting ideologies within the city-text of contemporary urban areas. Like the use of artifacts by an archaeologist, toponyms can be used by scholars in order to unveil city development as they reflect different stages in urban vicissitudes, including historical, social, linguistic, economic, and political changes over generations. In actuality, place names may reflect every aspect of human life over long time periods, from the early use of the land for agricultural purposes to the development of early human settlements and the exploitation of natural resources that historically increased during the urbanization process that started at the beginning of the Anthropocene.

\section{Warfare activities during the Anthropocene and their influence on toponymy}

During the Anthropocene, warfare involved an area of land worldwide ( $10.8 \mathrm{M} \mathrm{km}^{2}$ ) more than double that of urbanized areas (Capra et al. 20I5 b). Warfare not only represents one of the most important human geomorphic activities, but also magnifies many other human activities over a duration that extends beyond the period of combat (Syvitski and Kettner 20II). Thus, warfare activities could serve as an important driving force in addressing toponymic inscription, and this appears to be particularly true in an epoch, as the Anthropocene, that has been characterized by some of the most devastating warfare in human history.

Notably, many battles have been named after some feature of battlefield geography. As a counterpoint, many place names changed their meaning after important battlefields. These place names not only called to mind a geographical entity, but were often metonymously used to indicate the battles that were fought in those areas. This demonstrates how intensive and mutual the relationship between warfare and toponymy can be.

Both during and after the end of warfare, many places, including areas that were not part of the hostilities, change their toponymy. To illustrate, anti-German sentiment was common among the nations that opposed it during both world wars. As a consequence of the politically semiotic process, termed "toponymic cleansing" (Azaryahu 20II), many German and German-sounding place names in USA were permanently or even temporary renamed. For instance, the toponym Berlin was changed to Marne in Michigan and the locality once known as Germania was replaced with the place name Lakota in Iowa. In Australia the same sentiment was at the base of the renaming of hundreds of places that were either anglicized (from 
Rosenthal to Rosedale), or replaced with names from Aboriginal languages. (from Heidelberg to Kobandilla) or named in memory of war heroes (from Germanton to Holbrook) or epic battlefields (from Grunthal to Verdun).

Following WWI and the Greco-Turkish War (I9I9-22), the names of more than 4400 settlements were officially changed in many Greek regions (NHRF [National Hellenic Research Foundation] 20I 5). As a consequence of the Treaty of Neuilly and Lausanne, many people were forced to migrate between Greece, Yugoslavia, Bulgaria, and Turkey. In Greece, the areas left free by Bulgarians and Muslims were resettled by Greeks from Asia Minor and the Balkans. The toponyms of Slavic-Macedonian, Turkish, Vlach, or Albanian origin were replaced with Greek names following a "Hellenization" ideology that completely reshaped the toponymic configuration of the area.

From a worldwide perspective, many other countries (for instance, New Zealand, Canada, Belgium, Italy, France) were affected by the same cleansing as a direct consequence of this imaginary, often utopian, semantic Toponymic World War. From this point of view, WWI could probably be considered as the event responsible for one of the first massive Toponymic Revolution in human history. Before this event, no other human activity had been able to modify the toponymy of vast areas in so short a time. Other human activities, such as urbanization and agriculture, with their capacity to shape vast portions of the landscape, have previously been able to influence the toponymy of large areas but in historical times spanning centuries or even millennia.

Compared with WWI, WWII probably may have had less impact on political place-name practices because, as argued by Balzani (2009), the need to produce a continual flow of names during the post-WWII period significantly alters that political-patriotic and historical-pedagogical imprint that enormously influenced the post-WWI toponymy. Additionally, trench warfare, with its capacity to physically modify the geographic space and consequently rename it, had become largely obsolete by the start of WWII. However, there are several paradigmatic examples of massive renaming procedures such as those that occurred in the areas conquered by the former Soviet Union. In 1946, after the forced removal of the German inhabitants, the city of Königsberg was annexed to the Soviet Union and in a chauvinistic-justified damnatio memoriae renamed as Kaliningrad in honor of the Stalinist functionary. Most of the towns and villages in the same region were similarly named, while more than 200 important towns in all Soviet countries were renamed in order to celebrate Russian public figures (David 20II). Following the same ideological pattern, Poland, as a result of WWII agreements, acquired an important slice of German territories of approximately $103,000 \mathrm{~km}^{2}$. In 1946, the Committee for Settling of Place Names was established, and many Polish scholars were actively involved in this project. By the end of I950, more than 32,000 toponyms had been determined by the Commission (Yoshioka 2007), showing how intensive the toponymic reaffirmation of the old Polish roots was.

After the tremendous two world wars, civil conflicts and terrorism were, and currently are, the most common form of warfare during the Anthropocene. The 
consequences of civil wars and terrorism on place-naming practices can be shown by few paradigmatic examples. Saigon, became Ho Chi Minh City in I976 after the North defeated the South and its US allies in the Vietnam War. Additionally, the province of Gia Định and three important suburban districts were definitively combined and renamed in a single urban area in honor of the late Communist leader (Palagiano 2013). After just one year from the bloody suppression of a popular uprising, the ruling military junta of Burma changed its name to Myanmar (the written, literary name of the country), justifying the choice in the concept, explicated in the so-called "Adaptation of Expressions Law," to lessen ethnic problem (Steinberg 2010). Under the same auspices an emblematic "soft toponymic regime" involved many other place names of regions, cities, divisions, archipelagos, and rivers. In New York, just a few hours after the attacks, several media agencies began using the term Ground Zero to refer to the World Trade Center. The Freedom Tower name was coined in 2003, as a symbol of the resolve and determination of US Americans to react against terrorism (Rose 2013).

Lastly, the previously reported examples show the main side of the question but say nothing about the "dark side of the moon," such as the indirect consequences of the new massive human migration from countries affected by severe conflicts caused by more recent civil wars and terrorist organizations. Hundreds of thousands of peoples, mainly coming from states involved in the so-called Arab Spring, have recently been forcibly displaced from their native countries. Consequently, waves of refugees recently have poured into Europe along its southern borders. What will become of these people is currently a matter of heated debate in the European political arena, but any decision will generate geographical and, consequently, toponymic consequences. A new field of investigation that scholars involved in toponymy may well be asked to investigate in the near future.

\section{New frontiers in toponymy during the Anthropocene}

Scholars have suggested several new directions, especially in the investigation of critical and political toponymy (Rose-Redwood and Alderman 20I I). However, another interesting case could be detected from "planetary toponymy" (El-Baz I980).

In the so-called Western world, the practice of naming lunar and planetary features started more than 400 years ago, when the first lunar place names, i.e., terrae from the Latin "land" and maria for "seas," were coined by Galilei. In I922, just three years after it had been founded, the International Astronomical Union (IAU) appointed a committee to standardize lunar nomenclature. In I973, the IAU was substantially reorganized and expanded, becoming the Working Group for Planetary System Nomenclature (WGPSN). Even through the IAU established specific rules and guidelines for officially naming a celestial body or some of its features, there are still unexpected unofficial ways to buy the naming rights. This is the new market of the planetary toponymy, which finds its roots on the web where hundreds of companies propose this "stellar 
purchase" at a moderate price. Even non-profit organizations, such as the Sydney Observatory's Name A Star program, have proposed the same possibility by a "fully tax-deductible" donation. It appears to be a debatable issue, but the awesomeness of the business around this market has been demonstrated by the astonished and even worried reactions of the scientific community and media. The IAU recently published a specific communication reaffirming that the association "dissociates itself entirely from the commercial practice of selling fictitious star names" (Andersen 2016). Other worldwide scientific societies, such as the International Planetarium Society, published similar concerned statements, while important media have issued a warning to prevent people from throwing "money into a black hole" (Friedlander 20I4).

The idea that this type of new frontier in toponymic inscription is a prominent socio-economic consequence of human society is based on the recognition that this business has been entirely created during the internet era. Additionally, even if this situation may appear to be frivolous, the use of toponymy as a commodity represents an increasing business worldwide with serious socio-economic consequences. If during the near future, private companies try to capitalize upon this new marketing strategy, this development will be a concern for future scholars however, as it is the "commodification of place-naming rights" (Rose-Redwood and Alderman 20II) appears to be a fixed part of our neoliberal Anthropocene era.

\section{Conclusions}

During the Anthropocene, humans have largely rewritten the natural and urban text, and place names provide the chronicle of this new history. With the advent of the Industrial Revolution, and the consequent increase in urbanization, toponymic inscription has been overwhelmed by a revolution in both qualitative and quantitative terms. Before this turning point, the natural features of the landscape and the early human settlement with related activities were the main "objects" codified through place-naming practices. At the beginning of the "human age," such complex performative practices completely changed, with most "modern names" coined to mainly indicate the "artificial" human-made features of an increasingly anthropogenically modified environment. Such comodification of the physical environment versus toponymic twisting mainly occurred in urbanized and warfare-affected areas. Urbanonyms and technogenonyms represent just the more blatant consequences of such a revolution, while the neoliberalization of urban spaces and even extraterrestrial bodies, through the commodification of place-naming rights, is one of the real "encoded fingerprints" of this new era.

\section{Disclosure statement}

No potential conflict of interest was reported by the authors. 


\section{Bibliography}

Andersen, Johannes. 2016. "Buying Stars and Star Names.” Accessed January 25 2018. https://www.iau. org/public/themes/buying_star_names/

Azaryahu, Maoz. 20II. "The Critical Turn and Beyond: The Case of Commemorative Street Naming." ACME: An International Journal for Critical Geographies Iо: 28-33.

Balzani, Roberto. 2009. "Urban Toponymy, Cultural Memory and the World Wars." In Memories and Representations of War, edited by Elena Lamberti and Vita Fortunati, 90-I02. Amsterdam-New York: Rodopi.

Berg, D Lawrence, and Jani Vuolteenaho. 2009. Critical Toponymies: The Contested Politics of Place Naming. Aldershot: Ashgate.

Buondonno, Andrea, Gian Franco Capra, Daniela Di Palma, Eleonora Grilli, and Renata Concetta Vigliotti. 20I8. "Pedotechnologies for the Environmental Reclamation of Limestone Quarries: A Protocol Proposal." Land Use Policy 7I: 230-44.

Buondonno, Andrea, Eleonora Grilli, Gian Franco Capra, Carmen Glorioso, Alessio Langella, Antonio Leone, Nicole Leone, Pierclaudio Odierna, Sergio Vacca, and Renata Concetta Vigliotti. 20 I $3 .^{2}$ "Zeolitized Tuffs in Pedotechnique for the Reclamation of Abandoned Quarries: A Case Study in the Campania Region (Italy)." Journal of Environmental Management I 22: 25-30.

Capra, Gian Franco, Antonio Ganga, Andrea Buondonno, Eleonora Grilli, Carla Gaviano, and Sergio Vacca. 20I 5. "Ethnopedology in the Study of Toponyms Connected to the Indigenous Knowledge on Soil Resource.” PLOS One Io, no. 3: eог 20240.

Capra, Gian Franco, Antonio Ganga, Eleonora Grilli, Sergio Vacca, and Andrea Buondonno. 201 5. "A Review on Anthropogenic Soils from a Worldwide Perspective." Journal of Soils and Sediments I5, no. 7: I602-I 8 .

Capra, Gian Franco, Antonio Ganga, Peter Filzmoser, Carla Gaviano, and Sergio Vacca. 2016. "Combining Place Names and Scientific Knowledge on Soil Resources through an Integrated Ethnopedological Approach." CATENA I42: 89-Iог.

Capra, Gian Franco, Antonio Ganga, and Allan F. Moore. 2017. "Songs for Our Soils: How Soil Themes Have Been Represented in Popular Song." Soil Science and Plant Nutrition 63, no. 5: 517-25.

Coppola, Elio, Gian Franco Capra, Pierclaudio Odierna, Sergio Vacca, and Andrea Buondonno. 20 Io. "Lead Distribution as Related to Pedological Features of Soils in the Volturno River Low Basin (Campania, Italy)." Geoderma I 59, no. 3-4: 342-9.

Crutzen, Paul, and Eugene Stoermer. 2000. "The Anthropocene." IGBP Newsletter 4I: I2.

David, Jaroslav. 20I I. "Commemorative Place Names - Their Specificity and Problems." Names 59, no 4: 2I4-228.

El-Baz, Farouk. I980. "Lunar and Planetary Toponymy.” Air \& Space March-April: Io-I I.

Friedlander, Blaine. 20I4. "Buying a Star for a Holiday Gift is like "Throwing Money into a Black Hole"." The Washington Post. December 2

Hamlin, Frank R. I999. "Numbers in Placenames." Names 47, no. 3: 233-42.

Light, Duncan, and Craig Young. 20I4. "Toponymy as Commodity: Exploring the Economic Dimensions of Urban Place Names.” International Journal of Urban and Regional Research 39, no. 3: 435-50.

Mills, A. David. 2003. A Dictionary of British Place-Names. Oxford: Oxford University Press.

Monastersky, Richard. 20I 5. "The Human Age." Nature 519, no. 7542: I44-7.

NHRF (National Hellenic Research Foundation). 2015. Pandektis: Name Changes of Settlements in Greece. Athens: NHRF edition.

Palagiano, Cosimo. 20I3. "The Changing Toponymy: The Place Names and Their Vitality." Semestrale Di Studi E Ricerche Di Geografia 25, no. 2: 55-72.

Payne, Roger L. 200I. "Applied Toponymy in the United States." Names 49, no. 4: 293-9.

Post, Chris W., and Derek H. Alderman. 20I4. " "Wiping New Berlin off the Map": Political Economy and the De-Germanisation of the Toponymic Landscape in First World War USA.” Area 46, no. I: 83-9I.

Price, Patricia L. 2004. Dry Place: Landscapes of Belonging and Exclusion. Minneapolis, MN: University of Minnesota Press.

Rose, Sarah. 20I3. "No, That Isn"t Freedom Tower." The Wall Street Journal. June 23.

Rose-Redwood, Reuben. 2009. "Indexing the Great Ledger of the Community: Urban Housing, Numbering, City Directories and the Production of Spatial Legibility." In Critical Toponymies: The Contested Politics of Place Naming, edited by Lawrence Berg and Jani Vuolteenaho, I99-226. Aldershot: Ashgate. 
Rose-Redwood, Reuben. 20I r. "Rethinking the Agenda of the "New" Political Toponymy." ACME: $A n$ International Journal for Critical Geographies Io, no. I: 34-4I.

Rose-Redwood, Reuben, and Derek Alderman. 20II. "Critical Interventions in Political Toponymy." ACME: An International Journal for Critical Geographies ıo, no. I: I-6.

Rose-Redwood, Reuben, Derek Alderman, and Maoz Azaryahu. 20ro. "Geographies of Toponymic Inscription: New Directions in Critical Place-Name Studies.” Progress in Human Geography 34, no. 4: 453-70.

Savage, Victor. 2009. "Place Names." In International Encyclopedia of Human Geography, edited by Rob Kitchin and Nigel Thirift, I78-84. Amsterdam: Elsevier.

Steinberg, David I. 20I0. Burma/Myanmar: What Everyone Needs to Know. New York: Oxford University Press.

Swart, Mia. 2008. "Name Changes as Symbolic Reparation after Transition: The Examples of Germany and South Africa." German Law Journal 9, no. 2: 105-20.

Syvitski, James P. M., and Albert Kettner. 20II. "Sediment Flux and the Anthropocene." Philosophical Transactions of the Royal Society A 369, no. I938: 957-75.

Thériault, Marie Aurélie. 20I2. "Ethnolinguistic Investigation Methodology in an Urban Context: Microtoponymic and Toponymic Surveys.” International Journal of Social Science Research 2, no. 2: 266-75.

Tucci, Michele, Rocco Ronza, and Alberto Giordano. 20II. "Fragments from Many Pasts: Layering the Toponymic Tapestry of Milan." Journal of Historical Geography 37: 370-84.

Vuolteenaho, Jani, and Terhi Ainiala. 2009. "Planning and Revamping Urban Toponymy: Ideological Alterations in the Linguistic Landscaping of Vuosaari Suburb, Eastern Helsinki." In Critical Toponymies: The Contested Politics of Place Naming, edited by Lawrence Berg and Jani Vuolteenaho, 227-52. Aldershot: Ashgate.

Yoshioka, Jun. 2007. "Imagining Their Lands as Ours: Place Name Changes on Ex-German Territories in Poland after World War II." In Regions in Central and Eastern Europe: Past and Present, edited by Tadayuki Hayashi and Fukuda Hiroshi, 273-87. Sapporo: Slavic Research Center.

\section{Notes on contributors}

Gian Franco Capra is aggregate professor in soil science at the Department of Architecture, Design and Urban Planning of the University of Sassari. His research mainly deals with applied pedology, soil rebuilding, soil pollution, and the relationships between scientific and popular knowledge of soil science (ethnopedology).

Antonio Ganga has a $\mathrm{PhD}$ on ethnopedology and applied pedology at the Department of Architecture, Design and Urban Planning of the University of Sassari. His work focuses on the intersection of scientific and local knowledge of soil science.

Correspondence to: Dottor PhD Antonio Ganga, via Colombo n ${ }^{\circ}$ I, o8 го० Nuoro, Italy. Email: anto.ganga@gmail.com 